\title{
Abdominal Wall Prosthetic Repair in Ventral and Incisional Hernia Treatment: Classification, Terminology and Technical Aspects (Review)
}

D01. 10.17691/stm2015.72.19

Beceived August 26, 2014

V.V. Parshikov, MD, DSc, Professor, Department of Hospital Surgery named after B.A. Korolev;

A.A. Fedaev, PhD, Associate Professor, Department of Hospital Surgery named after B.A. Korolev

Nizhny Novgorod State Medical Academy, 10/1 Minin and Pozharsky Square, Nizhny Novgorod, 603005, Russian Federation

The review considers in detail the most important aspects of open abdominal wall prosthetic repair techniques applied in surgical treatment of ventral and incisional hernias according to contemporary foreign and domestic experience. We have presented the views of leading researchers on the use of synthetic endoprostheses. The authors have suggested a modern classification of primary ventral and incisional hernias indicating its variation from the previous classification SWR (Chevrel and Rath) and others. We have assessed and interpreted the English terms compared to those used in Russia. The review has traced the change of the term "tension-free plasty" in its historical perspective.

The work has presented the main up-to-date techniques for mesh endoprostheses implantation, their advantages and drawbacks. There have been estimated the key points of prosthetic repair surgeries in median abdominal wall closure. We have considered correct names of variants of surgeries depending on mesh placement in relation to hernia orifices, anatomical layers of abdominal wall, and self-tissue displacement.

We have clarified some peculiarities of operative techniques relying on intra-abdominal pressure control, and estimated the advantages and disadvantages of these techniques.

The review has specified the most urgent problems of modern herniology, and presented one of promising directions of surgical technique improvement in the treatment of patients with large ventral and incisional hernias. We have shown the necessity of proper usage and understanding of the implication of terms standing for operative interventions, as well as correct use of corresponding classifications and terminology for adequate comparison of our research results with those of our colleges.

Key words: incisional hernias; ventral hernias; prosthetic repair; tension-free plasty; abdominal wall reconstruction; mesh; intra-abdominal pressure.

Patients with abdominal wall hernias account for a significant part of patients in general surgery. It is due to the increase of the number and level of surgical interventions [1, 2], the development of operative techniques, the success of anesthesiology and intensive care. Hernias subsequently develop in $7-24 \%$ of patients who underwent midline laparotomy [3-7], especially after complications and/or relaparotomies [8]. The techniques of open abdomen and planned abdomen sanitations also lead to the formation of problematic category of cases: patients after a number of surgeries, those with acute tissue defects of the abdominal wall, which further formed large hernias with reduction of the abdominal cavity volume [9-12]. New medical technologies are no exceptions: after a widespread introduction of laparoscopy there is a group of patients with trocar hernias [13-15].

Despite the adoption of tension-free technique using synthetic implants, the recurrence rate is $10-60 \%[16$, 17]. Some surgeons still believe that the use of mesh had no effect on the treatment results of patients with complicated forms of hernias, in particular, large and giant incisional that led to improve autoplasty methods again [18]. It may happen that the problem of formation of hernias and their recurrences cannot be completely solved with exceptionally surgical approach because hernia has been found to be the metabolic and structure disorders in connective tissue that are genetically determined [17, 19-22]. No target therapy of this disease has been developed so far. The authors

For contacts: Parshikov Vladimir Vyacheslavovich, e-mail: pv1610@mail.ru 
indicate that the patients after prosthetic hernia repair have recurrences occurring in the first year after surgery [23]. On the other hand, disturbance in the connective tissue metabolism can be due to genetic features and prolonged existence of abdominal wall defects [24]. This fact does not contradict the data on morphological studies. The patients with hernias developed in the scar area have the remodeling of muscle and connective tissues resulting from degenerative and regenerative processes [25]. According to these data, the autoplasty is not very promising.

There are various classifications of abdominal hernias. The most popular among them in the former Soviet republics is that by Toskin's and Zhebrowski's, which is used most frequently by Russian doctors in general surgery $[26,27]$. For the representatives of Russian Hernia Society the SWR classification (Chevrel and Rath) is more common, it gaining acceptance first in Western Europe and then in Russia [17, 26-31]. However, the current classification of European Hernia Society (2009) [32] meets up-to-date requirements more and is to be recommended for its implementation in the Russian Federation in order to unify the approaches to the management of this category patients in our country and abroad. According to this classification all incisional hernias are divided by hernia orifice size. In contrast to the Chevrel and Rath, they are defined by width as W1 - small $(4 \mathrm{~cm})$, W 2 - moderate $(4-10 \mathrm{~cm}), W 3-$ large (over $10 \mathrm{~cm}$ ). Symbols $\mathrm{M}$ (midline) and $\mathrm{L}$ (lateral) indicate hernia localization, the latter referring to all defects lateral to the outer edge of the rectus sheath. Accordingly, the location of hernia orifice is indicated by M1 - subxifoidal (up to $3 \mathrm{~cm}$ from the xiphoid process), $\mathrm{M} 2$ - epigastric, M3 - umbilical (up to $3 \mathrm{~cm}$ above and below the navel), M4 - infraumbilical, M5 - suprapubic (up to $3 \mathrm{~cm}$ above the pubic tubercle), L1 - subcostal, L2 - flanc, L3 - iliac, L4 - lumbar. The presence of recurrence is referred to as $R$. Thus, the category of giant hernias is combined with large ones. In cases with multiple defects all the area of incompetent abdominal wall is taken as a basis.

The same publication [32] shows the classification of primary abdominal wall hernias. It also contains the $M$ and $L$ categories, but otherwise is considerably different from that of incisional hernias. Midline hernias include umbilical and epigastric defects. The lumbar and Spigelius's line defects are referred to lateral hernias. Hernias are divided by size in small $(2 \mathrm{~cm})$, medium $(2-4 \mathrm{~cm})$ or large (more than $4 \mathrm{~cm}$ ). No relapses are mentioned since any abdominal wall defect in the postoperative scar area is classified as incisional. Thus, the term "recurrent umbilical hernia" according to this classification is incorrect. One should also pay attention to the use of previously known terms: the concept of "primary abdominal wall hernia" is identical to the term "ventral", while all other hernia are referred to incisional abdominal wall hernias [32]. This information is to be taken into consideration when studying home and international practice.

In general, the experience of abdominal hernia treatment accounts for decades. There have been described many methods and operation techniques in this pathology. All proposed methods are divided into several categories. Autoplasty includes a number of techniques aiming at closing the abdominal wall defects using patient's tissues. This group includes the most commonly used surgical procedures. Prosthetic repair based on the use of mesh implants has become a new direction developed in modern herniology [29]. Mesh endoprostheses are made of various polymers, polypropylene being the most common. In addition to fully synthetic products, biological materials (xenopericardium) can be used for this purpose. The category of combined methods of abdominal wall defects closure is to be referred to the procedures involving both mesh use and the displacement of muscle and aponeurotic components for complete repair. The most common among them are those developed by Belokonev [29]. A number of Russian authors interpret the notion of combined techniques more widely and understand them as sublay technique. Abroad the above mentioned concepts are clearly distinguished as the terms "autoplasty" and "prosthetic repair" respectively. For the combination of autoplasty and mesh repair techniques the term "combined" is used that is inconsistent with the classical sublay operations.

Morphological changes have been proved to develop in abdominal wall tissues of patients with hernias [17]. Therefore, the success of autoplasty in hernia repair is so limited in some clinical situations. On the other hand, due to specific reasons, there are recurrences following prosthetic repair as well $[33,34]$. A defect closure method is recommended to choose according to a biomechanical concept of ventral hernia pathogenesis [35].

The issues of terminology in this section of surgery are laid special emphasis on. Leading national scientists have divided all prosthetic repair techniques into the abdominal wall reconstruction and correction [3638]. The first includes a complete restoration of the abdominal wall anatomy using a mesh. The second category involves the operations when the defect is closed by a mesh, the abdominal wall undergoing no significant changes. The suggested terms help to differentiate clearly various surgical techniques and they are recommended by the resolutions of the Conference of Russian Hernia Society. It is also the practice to divide all operations into open and endoscopic.

The positioning of an implant relative to hernia orifice is denoted by the terms onlay, sublay and inlay $[5,6$, 9, 39-42]. The leaders of the Russian Hernia Society repeatedly pointed out that these techniques should be understood, pronounced and reflected in medical records clearly and uniquely, just as they have been proposed by the authors [36, 38, 43]. Modern researchers support this point of view, because it allows surgeons and clinics in 
different countries to name certain operations accurately and correctly, as well as stratify patients, adequately assess and describe the results [39]. The term "onlay" is appropriate when the mesh is located above the defect, its edges can be sutured or not. The term "sublay" technique is used when the prosthesis is placed under the edges of hernia orifice and the latter is sutured over the implant. It is a basic technique in surgical treatment of incisional ventral hernias, it corresponding well to the "reconstruction" concept. The term "inlay" is used when a mesh is placed under the edges of hernia orifice, but the orifice is not sutured over the endoprosthesis. This technique meets the definition "correction". Abroad the terms "abdominal wall reconstruction" and "bridging repair" are considered to have much in common [41]. The term "underlay" is used quite rarely in foreign publications meets term, which is in exact accordance with the term "sublay". Russian surgeons do not use this term. Despite the fact it is long since the above mentioned surgical techniques and terms were widely introduced into practice, there is still different understanding of them. For example, in the study [44] sublay operations are presented both as lege artis, as well as in other variants. Likewise, in literature there are the descriptions of some modifications of basic methods, e.g., inlay-m technique, when a mesh is placed on the restored posterior wall of rectus sheath followed by abdominal white line reconstruction [45]. Some researchers divide the plasty in palliative and radical [46].

Currently, all mentioned prosthetic repair techniques are well known to be justified in common use [47]. However, the abdominal wall reconstruction is associated with a significantly lower relapse rate than bridging repair [48]. Prosthetic repair performed without rectus abdominis being replaced in its physiological position often leads to recurrence [49]. The transposition of these muscles in situ has been shown using a large cohort of patients to be able to achieve better results even in giant hernias and without using synthetic materials [50]. Moreover, it contributes to restoring the functional activity of these muscles [51]. Clinical results are in agreement with the understanding of morphological causes of recurrence after prosthetic repair that identified and described by Belokonev. The main point is in the characteristics of tissue responses on the border of the mesh fiber [34].

The use of onlay has been found to be associated with a great deal of wound complications, some authors also show the maximum frequency of chronic pain syndrome $[42,52]$. Nevertheless, a number of authors continue applying this method, developing special techniques to reduce the frequency of early complications [53-56]. The leaders of the Russian Hernia Society recommend the sublay technique as a treatment of choice, while inlay method is to be considered as a reserve technique and used as long as anatomical structures of the abdominal wall are difficult to differentiate [26, 36, 43]. In some situations, these basic techniques of prosthetic repair are to be combined, and the combination is to be specified: inlay-sublay, onlay-inlay [29, 45, 46].

A mesh can be located in relation to the abdominal wall layers intraperitoneally, preperitoneally, retromuscularly, and in some cases its location is subaponeurotic (premuscular) or supraaponevrotic (it more frequent corresponding to onlay) $[5,7,9,57-60]$. Sometimes intermuscular (intermuscular technique) position of a mesh is used. Most frequently it makes sense for prosthetic repair of the lateral segment of abdominal wall [61]. Other authors term the mesh placed between the external and internal oblique muscles as retromuscular technique too [62]. Intraperitoneal location of an implant corresponds abroad to the term "intraperitoneal onlay mesh" - IPOM [59, 63-66]. Similar abbreviations "intraperitoneal open hernioplasty" (IPOH) - are found rarely [58].

According to the decision of the $X^{\text {th }}$ Conference of the Russian Hernia Society, an implant made of synthetic material and used for abdominal wall defect closure was accepted to be named an endoprosthesis, implant or mesh, that agrees with the foreign terminology, while the terms graft, allograft or explant are to be avoided. The last mentioned terms are absolutely incorrect and have no relation to the modern hernia surgery $[26,38]$. Nevertheless, in Russian literature they are commonly used so far [62, 67-73].

The "prosthetic repair" concept continues to compete with the term "hernia repair", the later being not quite correct, though it has not been completely eliminated yet, while abroad the most frequently used terms are "prosthetic repair" or "abdominal wall reconstruction" rather than "hernioplasty"; the term "hernia repair" is uncommon [74, 75]. A number of Russian researchers suggest abolishng the terms "hernia repair" and "hernioplasty". The fact is that etimologically the terms "hernia repair" and "hernioplasty" are wide open to criticism. "Plasty" means the reconstruction of a certain natural anatomical structure, but not a hernia, which is pathological formation [38]. Moreover, the terms "hernioplasty" and "hernia repair" are still used even by the researchers, who are very scrupulous about the proper use of key terms [37, 70]. In some cases, authors use such word combinations as "hernioplasty of hernias" $[76,77]$.

The concept "prosthetic plasty" reflects the essence of surgical intervention and is related to the definition of tension-free technology that overseas corresponds to "tension-free repair" or "tension-free technique". In Russian literature there are very different views on the meaning of these terms. Some scientists understand these techniques (onlay, sublay and inlay) exactly as they have been proposed by foreign authors, and refer them to tension-free techniques making it difficult to disagree with [78]. It is particularly remarkable that the developers of these techniques indicated that according to tension-free technique the mesh should be fixed 
to the tissues without tension, but nothing was said how the abdominal wall wound should also be sutured without tension [78]. Many researchers consider the use of synthetic endoprostheses and tension-free technique to almost the same that is quite reasonable (i.e., onlay, sublay, inlay and laparoscopic mesh implantation are tension-free procedures) $[23,77]$. It should be specified that tension-free plasty includes the techniques for hernia surgery which do not result in intra-abdominal pressure (IAP) increase [79, 80]. They can be either those with implantation of a mesh (most frequently) or heterologous materials, or the procedures using the patient's own issue (autodermoplasty), or combined techniques. Preference to tension-free repair using synthetic materials in surgical treatment of patients with ventral and incisional hernias is the basis of modern hernia surgery.

Other scientists understand the tension-free technique differently. There is the classification by Egiev et al. [57], in which only onlay, inlay and onlay-inlay techniques are referred to tension-free procedures. The authors do not refer the sublay technique to tension-free in this work. Other scientists do not criticize this approach either [27]. Some researchers consider tension-free plasty apart from onlay, sublay and inlay procedures emphasizing that this technique is performed without reducing the abdominal cavity volume [81]. In some modern national publications onlay and sublay techniques are definitely named as tension $[70,82]$. The authors study the IAP dynamics and analyze the findings. Researchers pay their attention to IAP elevation in the postoperative period after sublay and onlay surgeries, and for this reason they make logical conclusions of specific benefits of this technique and that of Belokonev [70]. Nevertheless, other publications convincingly demonstrate IAP to increase always after surgery. There is evidence that severe intraabdominal hypertension (IAH) develops after all prosthetic repair techniques used including that of Belokonev [83]. However, other authors have obtained quite opposite results [84]. The study has shown a significant increase in IAP after sublay and inlay methods, while Belokonev technique has been said not to result in intra-abdominal hypertension [84]. However, a searching study of the results presented in the publication has revealed that all groups of patients, despite the differences found by the authors, had low (near normal) IAP levels and were unrelated to any pathology. Other authors have reported a small IAP increase after prosthetic repair in patients with W1-W2 hernias; moreover, no tension was used, since the researchers applied large-sized in their procedures [73].

It is quite obvious that all the cited works present different groups of patients, dissimilar approaches to the treatment and various surgical techniques. Normal and safe IAP levels have been published and are well known [85]. It must be admitted that IAP should not increase after technically correct tension-free repair by the end of surgery $[79,80]$. Postoperatively, there may be a transient increase of IAP that depends on a number of factors. In patients with 4-cm hernias even the use of autoplasty is not associated with the changes in respiratory function and central hemodynamics. After closing the defects of 4-8 cm in size using synthetic materials, no significant changes of the mentioned parameters are observed either. The surgical treatment of patients with hernia orifice over $8 \mathrm{~cm}$ in size results in significant deviations of major indices [86]. Similar findings were published by other authors [87]. A detailed examination of this problem reveals the following: IAP dynamics depends directly on orifice size and hernia volume [86]. In small hernias (umbilical, white line, small incisional, trocar) even the repair using a patient' $s$ own tissues has no significant effect in IAP increase. The recurrence frequency in this category is known to be relatively rarely even without mesh use. However, traditional methods are usually referred to tension technique [27, 57]. The use of autoplasty in small hernias is reasonable though not recommended as a method of choice. On the other hand, the results of prosthetic repair are significantly better even in small hernias [88].

Thus, any surgical procedure (sublay, inlay, onlay) in a certain situation may be performed as either tensionfree or tension, it depends on surgeon's experience, the compliance of a procedure, the size of hernia orifice and mesh. Perioperative IAP monitoring is described in detail and presents no difficulties [89]. There has been even suggested a ratio of tissue tension [90]. Some authors recommend the following: if in closing aponeurotic edges IAP does not exceed $20 \mathrm{~cm}$ of water column, onlay or sublay should be performed, in case IAP is higher, or aponeurotic edges are impossible to close - inlay technique is used [91]. According to the authors, this approach is effective and safe. On the other hand, such kind of technique is not to be called tension-free. There has been suggested a broad range of preoperative examination and assessment for patients to undergo the surgery [92].

Interesting data were obtained by Klokov. He intentionally performed only tension-free plasty and confirmed his survey by perioperative IAP monitoring data [79]. IAP was found to increase anyway in the postoperative period, the changes persisting for 7 days, and bandaging is of importance for venous hemodynamics even in a postoperative period. The author brought out clearly that IAP control is important both during surgery and in a postoperative period. In another study, the scientist compared the results of tension-free technique with those of the operations performed without pressure control [80]. Both groups in the postoperative period had increased IAP, but only after tension-free procedures IAP levels range within safe values.

In conclusion, the choice of the operation technique depends on a number of factors, and in a particular 
situation it is a team of surgeons and anesthesiologists who decide on a technique. However, it should be clearly understood that only tension-free procedures are safe for patients. Such techniques are favored abroad and in many Russian clinics [93, 94].

In large hernias the abdominal wall reconstruction is definitely associated with the risk of $\mathrm{IAH}$, as shown in the literature [83]. It is well known that a relatively small and short IAP elevation in many cases is not dangerous and easily tolerated in most patients. For a good example is laparoscopy known. However, among patients with large ventral hernias there are a significant number of people with initially high IAP level due to objective reasons (obesity, incarcerated hernia, intestinal obstruction). Some factors effecting IAP can be corrected during the surgery, while others cannot be. In certain cases it is difficult to determine the abdominal wall extensibility both to predict IAP dynamics and uncomplicated postoperative status of a patient. There should be taken into account both hernia defect size, and hernia volume [95]. The most important is maintaining the required volume of the abdominal cavity with adequate closure of the abdominal wall defect and prevention of compartment syndrome [96].

In some situations a long-term hernia presence leads to the reduction of abdominal cavity volume. In this case the hernia sac contains a significant part of visceral organs. The attempt of transposition of these organs in situ during the surgery results in the significant and persistent IAP increase. Therefore, it makes the abdominal wall reconstruction impossible without risk of fatal cardiovascular and respiratory complications.

The use of sublay technique in definite conditions is considered to be quite acceptable for small and mediumsized hernias, though in patients with large hernias it can present a tough problem. At the same time, the use of correction (inlay) in cases of large hernias has several advantages if the size of an endoprosthesis is adequate to that of the defect $[97,98]$. At a final stage of surgery, it is much easier for a surgical team to control IAP by choosing a mesh of adequate size that will enable if necessary to create an additional abdomen volume in cases of the abdominal cavity reduction due to a longterm hernia. A technically simple inlay technique may be even more secure concerning complications associated with increased IAP (acute respiratory failure, hypostatic pneumonia, venous thromboembolism). It is relevant just in the treatment of patients with large hernias, who can have hypercoagulability peaks in an early postoperative period [99]. On the other hand, pulmonary embolism can occur after both sublay and inlay techniques [68]. The resolution of IAH due to physiological abdominal wall distension and recovery of intestinal motility may take a long time that is the most dangerous in relation to life-threatening complications. It is noteworthy that the regression of impaired clotting is consistent with IAP reduction up to initial values $[79,80,99]$. A long-term use of high doses of anticoagulants is able to minimize these risks, but can result in the formation of large hematomas in the surgical site, as well as gastroduodenal bleeding.

On the other hand, after surgery the abdominal wall can become functionally adequate only if its normal anatomy is restored, primarily, after displacing the rectus abdominis muscles in their physiological position. Recently, it has been convincingly demonstrated in a number of studies $[50,51]$. We can assume that for the category of patients who are in critical condition due to the basic pathology and its complications, decompensated concomitant diseases, the main task for a surgeon and anesthesiologist are to correct hernia strangulation, intestinal obstruction, endotoxemia and vital functions disorders, while the abdominal wall defect is to be closed extremely fast using a simple technique, with complete IAP control of in full accordance with the tension-free plasty concept. In other cases the aim is to achieve abdominal wall functionally by performing an adequate abdominal wall reconstruction. It is of great importance in the restoration of physical activity and social adaptation of working age citizens.

Despite the advances in the prosthetic repair of patients with ventral and incisional hernias using the mentioned techniques, the problem of abdominal surgery is still far from being easily solved. There is a special category of patients with large (giant according to Toskin and Zhebrowski classification) hernias and abdominal cavity volume reduction (a term in English literature: loss of domain) [100]. The use of both basic tension-free procedures, as well as improved methods of abdominal wall defect closure in these patients are associated with IAH III degree development in a postoperative period [76, $83,101]$. It is no wonder that the mortality rate among such patients is still up to $5 \%[1,59,102]$ resulted from cardiovascular and pulmonary complications, multiple organ failure [102]. The most dangerous is the pulmonary embolism [99, 103]. Uncontrolled IAP increase and its consequences are considered to be the most important factors for their development [1]. Leading scientists with wide experience in the surgery of this category of patients emphasize that complying with the tension-free plasty principles and IAP control in these cases is of particular importance [104].

According to a meta-analysis (2014), the relapse rate in patients with giant hernias is 53\% [59]. In hernia surgery there is a number of methods developed to solve the problem, the most interesting of them being a components separation technique (CST) [105, 106]. The most famous technique is Ramirez procedure. It is a set of surgical techniques aimed at mobilization and separation muscular and aponeurotic structures in the medial and lateral segments of the abdominal wall. The features of such operations are described in detail in the foreign and national literature [67, 107-109]. The said manipulations help to achieve the necessary mobility of abdominal wall layers, their extensibility and 
ability to move to close a defect and create an additional abdominal cavity volume. The larger the size of the hernia orifice, the more lateral rectus abdominis muscles are located, and the main CST result will be the muscles replacement to their physiological position. CST can be used alone or to complement the prosthetic repair [59, $110,111]$. This procedure is permitted by the resolution of the $X^{\text {th }}$ Conference of Russian Hernia Society [26]. Now there has been gained extensive experience of combined use of the Ramirez surgery and the abdominal wall defects closure by an autodermal flap $[50,51]$. The problem of applying such operation in everyday practice is under active discussion.

In 2014, abroad there has been published the guidelines on laparoscopic surgery of abdominal wall hernias [112]. These operations are actively implementing in Russia [113, 114]. Nevertheless, the majority of surgeries in our country and many other countries are performed according to an open approach, especially in emergency surgery $[97,115,116]$. Unfortunately, neither national recommendations including the problems described nor European guidelines have been presented to Russian surgeons so far. In each specific case, a team of a surgeon and anesthesiologist is to decide on a surgical approach relying on their knowledge, abilities, resources and facilities of the clinic. It must be admitted that the Russian Federation needs multicenter randomized trials, as well as the development of national guidelines on the problem.

\section{References}

1. Pleshkov V.G., Agafonov O.I. Incisional ventral hernias - unsettled questions. Vestnik eksperimental'noy $i$ klinicheskoy khirurgii 2009; 3: 248-255.

2. Timerbulatov M.V., Timerbulatov Sh.V., Gataullina E.Z., Valitova E.R. Incisional ventral hernias: the current state of the problem. Meditsinskiy vestnik Bashkortostana 2013; 5: 101-107.

3. Tashkinov N.V., Boyarintsev N.I., Kulikova N.A., Panenkov A.N., Bel'mach V.P. Selection of preventive endoprosthetic technique in median laparotomy. Dal'nevostochnyy meditsinskiy zhurnal 2014; 1: 38-40.

4. Sopuev A.A., Tilekov E.A., Umurzakov O.A., Abdiev A.Sh., Ovcharenko K.E. Evaluation of continuous suturing of the anterior abdominal wall at laparotomy access. Sovremennye problemy nauki i obrazovaniya 2013; 6. URL: http://www.science-education.ru/113-10864.

5. Kingsnorth A.N. The management of incisional hernia. Ann R Coll Surg Engl 2006; 88(3): 252-260, http://dx.doi.org/ 10.1308/003588406X106324.

6. Berger D., Lux A. Operative therapie der narbenhernie. Der Chirurg 2013; 84(11): 1001-1012, http://dx.doi. org/10.1007/s00104-011-2245-y.

7. Hanna E.M., Byrd J.F., Moskowitz M., Mann J.W.F., Stockamp K.T., Patel G.N., Beneke M.A., Millikan K., lannitti D.A. Outcomes of a prospective multi-center trial of a second generation composite mesh for open ventral hernia repair. Hernia 2014; 18(1): 81-89, http://dx.doi.org/10.1007/s10029013-1078-7.

8. Shakirova A.R., Smolkina A.V., Khusainov Sh.l.,
Gerasimov N.A., Barinov D.V., Rogova Yu.Yu., Prokina E.F. Long-term results of surgical treatment of patients after relaparotomy. Sovremennye problemy nauki i obrazovaniya 2013; 4. URL: http://www.science-education.ru/110-9902.

9. Kingsnorth A.N. Hernia surgery: from guidelines to clinical practice. Ann R Coll Surg Engl 2009; 91(4): 273-279, http://dx.doi.org/10.1308/003588409X428540.

10. Dietz U.A., Wichelmann C., Wunder C., Kauczok J., Spor L., Strauß A., Wildenauer R., Jurowich C., Germer C.T. Early repair of open abdomen with a tailored two-component mesh and conditioning vacuum packing: a safe alternative to the planned giant ventral hernia. Hernia 2012; 16(4): 451-460, http://dx.doi.org/10.1007/s10029-012-0919-0.

11. Löpez-Cano M., Pereira J.A., Armengol-Carrasco M. "Acute postoperative open abdominal wall": nosological concept and treatment implications. World J Gastrointest Surg 2013; 5(12): 314-320, http://dx.doi.org/10.4240/wjgs.v5.i12.314.

12. Brandl A., Laimer E., Perathoner A., Zitt M., Pratschke J., Kafka-Ritsch R. Incisional hernia rate after open abdomen treatment with negative pressure and delayed primary fascia closure. Hernia 2014; 18(1): 105-111, http:// dx.doi.org/10.1007/s10029-013-1064-0.

13. Armacañzas L., García-Peche P., Ruiz-Tovar J., Arroyo A., Armañaczas E., Díez M., Galindo I., Calpena R. Closure of the umbilical trocar site with prophylactic mesh versus suture after laparoscopic cholecystectomy in highrisk patients for incisional hernia. Hernia 2014; 18(Suppl 2): S50.

14. Feleshtynsky Y.P., Dadayan V.A., Vatamanyuk V.F., Smishchuk V.V. Special aspects of alloplasty of port-site hernias with diastasis rectiabdominis. Hernia2014; 18(Suppl 2): S92.

15. Otero de Pablos J., Peña Soria M.J., Cabeza Gomez J.J., Jimenez-Valladolid Condes D., Torres García A.J., Delgado Lillo I. Incidence of port site incisional hernia after laparoscopic procedures in a tertiary hospital. Hernia 2014; 18(Suppl 2): S102.

16. Lauscher J.C., Loh J.C., Rieck S., Buhr H.J., Ritz J.P. Long-term follow-up after incisional hernia repair: are there only benefits for symptomatic patients? Hernia 2013; 17: 203-209, http://dx.doi.org/10.1007/s10029-012-0955-9.

17. Alishev O.T., Shaimardanov R.Sh. The current situation and problems in treatment of large postoperative ventral hernias. Prakticheskaya meditsina 2013; 2: 16-21.

18. Karapysh D.V. Giant incisional hernias, complicated by acute ileus as the most difficult issue of urgent surgery and the ways of its solution. Vestnik novykh meditsinskikh tekhnologiy 2013; 3: 88-91.

19. Bart I.I., Ivanov I.S., Lazarenko V.A., Ivanov V.P. Association of ratio of collagenes in the aponeurosis of the abdominate with a matrix metalloproteinase genes polymorphisms. Fundamentalnie issledovania 2013; 2(part 1): 28-34.URL:http://www.rae.ru/fs/?section=content\&op=\&article_ $\mathrm{id}=10000258$.

20. Ivanov I.S., Lazarenko V.A., Ivanov S.V., Goryainova G.N., Ivanov A.V., Tarabrin D.V., Litvyakova M.I. Type 1 and 3 collagen ratio in skin and aponeurosis in patients with ventral hernias. Novosti khirurgii 2013; 3: 33-36.

21. Franz M.G. The biology of hernia formation. Surg Clin North Am 2008; 88(1): 1-15, http://dx.doi.org/10.1016/ j.suc.2007.10.007.

22. Calaluce R., Davis J.W., Bachman S.L. Incisional hernia recurrence through genomic profiling: a pilot study. Hernia 
2013; 17(2): 193-202, http://dx.doi.org/10.1007/s10029-0120923-4.

23. Dambaev G.Ts., Khokhlov K.S., Gabidulina N.V., Shcheglov A.V. Reconstructive surgery in patients with postoperative ventral hernia. Sibirskiy meditsinskiy zhurnal (Tomsk) 2011; 2(part 1): 121-124.

24. Bogdan V.G., Gain Yu.M. Pathogenesis of incisional hernias: connective tissue metabolism change - cause or effect? Novosti khirurgii 2011; 6: 29-35.

25. Grigoryuk A.A. The structure of aponeurosis the anterior abdominal wall rights in norm and pathology. Vestnik novykh meditsinskikh tekhnologiy 2011; 2: 104-106.

26. Rezolyutsiya $X$ nauchnoy konferentsii "Aktual'nye voprosy gerniologii" [Resolution of $X$ scientific conference "Urgent problems of herniology"]. Moscow; 2013. URL: http:// herniaweb.ru/index.php?cat_id=30.

27. Sherbatykh A.V., Sokolova S.V., Shevschenko C.V. The modern state of problem of postoperative ventral hernias surgical treatment. Sibirskiy meditsinskiy zhurnal (Irkutsk) 2010; 4: 11-16.

28. Chevrel J.P., Rath A.M. Classification of incisional hernias of the abdominal wall. Hernia 2000; 4(2): 94, http:// dx.doi.org/10.1007/bf02353754.

29. Pushkin S.Yu., Belokonev V.I. Treatment of medial ventral hernias with the use of synthetic endoprosthesis. Khirurgiia. Zhurnal im. N.I. Pirogova 2010; 6: 43-45.

30. Kulikov L.K., Buslaev O.A., Shalashov S.V., Smirnov A.A., Mikhaylov A.L., Egorov I.A., Shadarov L.P., Sobolev S.T., Sobotovich V.F., Privalov Yu.A. Surgical treatment of extensive and giant incisional ventral hernias. Novosti khirurgii 2013; 2: 37-44.

31. Shturich I.P. Management of patients with incisional ventral hernias. Vestnik Vitebskogo gosudarstvennogo meditsinskogo universiteta 2012; 2: 71-77.

32. Muysoms F.E., Miserez M., Berrevoet F., Campanelli G., Champault G.G., Chelala E., et al. Classification of primary and incisional abdominal wall hernias. Hernia 2009; 13(4): 407-414, http://dx.doi.org/10.1007/s10029-009-0518-x.

33. Belokonev V.I., Zhitlov A.G., Vavilov A.V. Pathomorphological rationale of surgical treatment principles of patients with incisional ventral hernia. Byulleten' meditsinskikh internet-konferentsiy 2011; 6: 62-102.

34. PonomarevaY.V.,BelokonevV.I.,VolovaL.T.,GulyaevM.G. The morphological basis of the causes of recurrence in patients with postoperative ventral hernias. Fundamentalnie issledovania 2013; 9(part 2): 263-266. URL: http://www.rae.ru/fs/?section= content\&op=show_article\&article_ id $=10001467$.

35. Belokonev V.I., Fedorina T.A., Pushkin S.Yu., Nagapetyan S.V. Morphological substantiation of biomechanical concept of ventral hernia pathogenesis. Morfologicheskie vedomosti 2009; 3(part 4): 121-124.

36. Timoshin A.D., Shestakov A.L., Yurasov A.V., TitovV.V., Kalachev I.I. Problems of terminology in the anterior abdominal wall hernia surgery. Ambulatornaya khirurgiya. Statsionarozameshchayushchie tekhnologii 2007; 4: 227.

37. Nikitin N.A., Korshunova T.P., Golovin R.V. On the necessity of terminology uniformity in surgery of postoperative ventral hernias. Sovremennye problemy nauki $i$ obrazovaniya 2014; 2. URL: http://www.science-education. $\mathrm{ru} / 116-12793$.

38. Upyrev A.V. O ponyatiyakh i terminakh v sovremennoy gerniologii: 7 let spustya, sleduet li obsudit' problemu snova? V kn.: Materialy X konferentsii "Aktual'nye voprosy gerniologii"
[On concepts and terms in modern herniology: 7 years later, should the problem be discussed again? In: Proceedings of $X$ conference "Urgent problems of herniology"]. Moscow; 2013; p. $152-154$.

39. Lembas A.N., Tampey I.I., Kuchinskiy M.V., Baulin A.V., Baulin V.A., Ivanchenko V.V., Velishko L.N., Velishko S.I., Pigovich I.B. Surgical treatment of recurrent incisional ventral hernias. Ukrainskiy zhurnal khirurgii 2013; 4(23): 59-63.

40. Andersen L.P.H., Klein M., Gögenur I., Rosenberg J. Long-term recurrence and complication rates after incisional hernia repair with the open onlay technique. BMC Surg 2009; 9: 6, http://dx.doi.org/10.1186/1471-2482-9-6.

41. Nockolds C.L., Hodde J.P., Rooney P.S. Abdominal wall reconstruction with components separation and mesh reinforcement in complex hernia repair. BMC Surgery 2014, 14: 25, http://dx.doi.org/10.1186/1471-2482-14-25.

42. Venclauskas L., Maleckas A., Kiudelis M. Onlay versus sublay technique of incisional hernia treatment. A prospective randomized study. Results of five years follow-up. Hernia 2014; 18(Suppl 2): S13.

43. Timoshin A.D., lurasov A.V., Shestakov A.L. Conference "Actual problems of herniology". Khirurgiia. Zhurnal im. N.I. Pirogova 2007; 7: 80.

44. Markova Ya.A. Selection of hernoplasty technique and postoperative surveillance of patients with ventral hernias. Novosti khirurgii 2012; 5: 24-31.

45. Beloborodov V.A., Tsmaylo V.M., Kolmakov S.A., Kuz'menko K.P. Treatment results of patients with incisional ventral hernias. Byulleten' Vostochno-Sibirskogo nauchnogo tsentra SO RAMN 2012; 4(part 1): 15-17.

46. Beloborodov V.A., Tsmaylo V.M., Kolmakov S.A. The results of surgical correction of incisional ventral hernias. Sibirskoe meditsinskoe obozrenie 2012; 6: 63-66.

47. Shell D.H., de la Torre J., Andrades P., Vasconez L.O. Open repair of ventral incisional hernias. Surg Clin North Am 2008; 88: 61-83, http://dx.doi.org/10.1016/j.suc.2007.10.008.

48. Booth J.H., Garvey P.B., Baumann D.P., Selber J.C., Nguyen A.T., Clemens M.W., Liu J., Butler C.E. Primary fascial closure with mesh reinforcement is superior to bridged mesh repair for abdominal wall reconstruction. J Am Coll Surg 2013; 217(6): 999-1009, http://dx.doi.org/10.1016/j.jamcollsurg.2013. 08.015 .

49. Fedoseev A.V., Murav'ev S.Yu., Avdeev S.S., Gazuani A.I. Functional mechanisms of abdominal raphe, and their role in ventral hernia pathogenesis. Rossiyskiy medikobiologicheskiy vestnik im. akademika I.P. Pavlova 2013; 4: 154-161.

50. Botezatu A.A. Vybor metoda plastiki bol'shikh i gigantskikh posleoperatsionnykh, retsidivnykh sredinnykh gryzh zhivota. V kn.: Materialy X nauchnoy konferentsii "Aktual'nye voprosy gerniologii" [The choice plastic repair techniques of large and giant incisional median abdominal recurrent hernias. In: Proceeding of $X$ scientific conference "Urgent problems of herniology"]. Moscow; 2013; p. 28-30.

51. Raylyanu R.I., Botezatu A.A., Kovalenko T.N., Burlak V.A., Karaman L.A. Vosstanovlenie funktsiy myshts zhivota posle rekonstruktivnoy gernioplastiki. $\mathrm{V}$ kn.: Materialy $X$ nauchnoy konferentsii "Aktual'nye voprosy gerniologii" [Functional recovery of abdominal muscles after reconstructive hernioplasty. In: Materials of X scientific conference "Urgent problems of herniology"]. Moscow; 2013; p. 130-132.

52. Shcherbatykh A.V., Sokolova S.V., Shevchenko K.V. The comparison of efficiency of different surgical approaches 
in the treatment of incisional ventral hernias. Vestnik eksperimental'noy i klinicheskoy khirurgii 2012; 1: 80-82.

53. Kukosh M.V., Vlasov A.V., Gomozov G.I. Prevention of early incisional complications in ventral hernia prosthetic repair. Novosti khirurgii 2012; 5: 32-37.

54. Vlasov A.V., Kukosh M.V. The problem of wound complications in abdominal wall endoprosthesis replacement in ventral hernias. Sovremennye tehnologii v medicine 2013; 5(2): 116-124.

55. Aleksandrenkov N.V., Mukhin A.S., Rebtsovskiy V.A., Leont'ev A.E. Wound closure technique in epi-aponeurotic repair of large incisional ventral hernias with polypropylene mesh. Novosti khirurgii 2013; 1: 88-93.

56. Jamal K., Ratnasingham K., Shaunak S., Ravindran K., Nehra D. A novel technique for modified onlay incisional hernia repair with mesh incorporation into the fascial defect: a method for addressing suture line failure. Hernia 2013, http://dx.doi. org/10.1007/s10029-013-1195-3. [Epub ahead of print].

57. Egiev V.N., Lyadov K.V., Voskresenskiy P.K. Atlas operativnoy khirurgii gryzh [Handbook of hernia operative surgery]. Moscow: Medpraktika-M; 2003; 228 p.

58. Beltran M.A., Rioseco M.-P., Molina M., Vera A., Arcos F.R. Outcomes of open intraperitoneal incisional hernia repair based on patient-reported outcomes. Hernia 2014; 18(1): 47-55, http://dx.doi.org/10.1007/s10029-012-1041-z.

59. Eriksson A., Rosenberg J., Bisgaard T. Surgical treatment for giant incisional hernia: a qualitative systematic review. Hernia 2014; 18(1): 31-38, http://dx.doi.org/10.1007/ s10029-013-1066-y.

60. Augenstein V.A., Belyansky I., Kercher K.W., Heniford B.T. Preperitoneal mesh repair for complex ventral hernias: a prospective study of 768 consecutive patients. Hernia 2014; 18(Suppl 2): S97.

61. Yampolsky I. Difficulties in reconstruction the abdominal wall in huge complex lateral incisional hernias. Hernia 2014; 18 (Suppl 2): S9.

62. Brekhov E.I., Iurasov A.V., Gribunov lu.P., Repin I.G., Alekseev A.K., Cherniaeva N.A., Zhitnikov G.V. Diagnostics and surgical correction of postoperative myofascial defects of lateral abdominal wall and lumbar region. Khirurgiia. Zhurnal im. N.I. Pirogova 2009; 10: 10-14.

63. Grigor'ev S.G., Krivoshchekov E.P., Grigor'eva T.S., Kostin A.Yu. New and old in the problem of hernia sac treatment in inguinal, umbilical and incisional ventral hernias. Vestnik eksperimental'noy i klinicheskoy khirurgii 2011; 2: 264-268.

64. Grigoriev S.G., Krivoshchekov E.P., Grigorieva T.S., Kostin A.Yu. eatures of intra-abdominal endorosthetic repair of umbilical and incisional ventral hernias. Saratovskiy nauchnomeditsinskiy zhurnal 2012; 1: 141-145.

65. Lasses Martínez B., Peña Soria M.J., Cabeza Gomez J.J., Jimenez Valladolid D., Josa Martínez M., Torres García A., Delgado Lillo I. Treatment of large incisional hernias with intraperitoneal composite mesh: our experience and results in 85 patients. Hernia 2014; 18(Suppl 2): S100.

66. Roy S., Shnoda P., Savidge S., Hammond J., Panish J., Wilson M. Surgery stress in open ventral hernia repair: a comparison of hand-sutured vs mechanical fixation of intraperitoneal onlay mesh (IPOM) in a pre-clinical model. Hernia 2014; 18(Suppl 2): S109.

67. Vinnik Yu.S., Petrushko S.I., Nazaryants Yu.A., Kochetova L.V., Pakhomova R.A., Kuznetsov M.N., Markelova N.M., Vasilenya E.S., Soloveva N.S. Modern condition of the question on methods of surgical treatment of hernias of the forward belly wall. Sovremennye problemy nauki i obrazovaniya 2013; 1. URL: http://www.science-education.ru/107-8180.

68. Tsverov I.A., Bazaev A.V. The assessment of main alloplasty techniques in order to optimize the treatment of patients with postoperative ventral hernias. Sovremennye tehnologii v medicine 2011; 2: 73-76.

69. Tsverov I.A., Bazaev A.V. Surgical treatment of patients with ventral hernias: modern state. Sovremennye tehnologii $v$ medicine 2010; 4: 122-127.

70. Nikitin N.A., Goloviznin A.A., Golovin R.V. Choice of the method of combined alloherinia plastic interventions in postoperative ventral hernias of median localisations. Fundamentalnie issledovania 2014; 4-3: 572-577. URL: http:// www.rae.ru/fs/?section $=$ content $\& o p=$ show_article\&article_ id $=10003231$.

71. Malkov I.I., Tverdokhleb I.V. Abdominal wall tissue changes after experimental alloplasty. Klinicheskaya $i$ eksperimental'naya morfologiya 2013; 3(7): 56-59.

72. Ragimov V.A. Comparative analysis of the results of alloplastic techniques in surgical treatment of ventral hernias. Vestnik eksperimental'noy $i$ klinicheskoy khirurgii 2012; 3: 574-577.

73. Pepenin A.V., loffe I.V., Alekseev A.V. First experience of using Physiomesh in ventral hernioplasty. Vestnik neotlozhnoy i vosstanovitel'noy meditsiny 2014; 2: 159-161.

74. Moazzez A., Mason R.J., Darehzereshki A., Katkhouda N. Totally laparoscopic abdominal wall reconstruction: lessons learned and results of a shortterm follow-up. Hernia 2013; 17(5): 633-638, http://dx.doi. org/10.1007/s10029-013-1145-0.

75. Fischer J.P., Shang E.K., Butler C.E., Nelson J.A., Braslow B.M., Serletti J.M., Kovach S.J. Validated model for predicting postoperative respiratory failure: analysis of 1706 abdominal wall reconstructions. Plast Reconstr Surg 2013; 132(5): 826-835, http://dx.doi.org/10.1097/ prs.0b013e3182a4c442.

76. Charyshkin A.L., Frolov A.A. Way hernioplasty big and huge postoperative ventral of hernias. Fundamentalnie issledovania 2013; 11-1: 100-103. URL: http://www.rae.ru/fs/ ?section=content\&op=show_article\&article_id=10002285.

77. Nekrasov A.Yu., Kasum'yan S.A., Vorontsov A.K., Sergeev A.V., Bezaltynnykh A.A. Tension-free hernioplasty of incisional ventral hernias. Novosti khirurgii 2011; 2: 21-25.

78. Korenkov M., Paul A., Sauerland S., Neugebauer E., Arndt M., Chevrel J.P., Corcione F., Fingerhut A., Flament J.B., Kux M., Matzinger A., Myrvold C.E., Rath A.M., Simmermacher R.K.J. Classification and surgical treatment of incisional hernia. Langenbeck's Arch Surg 2001; 386(1): 6573, http://dx.doi.org/10.1007/s004230000182.

79. Klokov V.A. The effect of abdominal bandage on venous circulatory dynamics in patients with large ventral hernias. Sibirskoe meditsinskoe obozrenie 2012; 3: 67-70.

80. Klokov V.A. The significance of "tension-free" repair of hernia effect in thromboembolic event prevention in patients with incisional ventral hernias. Sibirskiy meditsinskiy zhurnal (Irkutsk) 2012; 2: 20-22.

81. Evseev M.A., Golovin R.A., Sotnikov D.N., Lazaricheva N.M. Peculiarities of surgical approach in incisional ventral hernias in patients of old and senile age. Vestnik eksperimental'noy i klinicheskoy khirurgii 2011; 1: 10-16.

82. Golovin R.V., Nikitin N.A., Prokopiev A.A. Prognosis of development of complications of injuries after combined allohernia plastic interventions for postoperative ventral 
hernias of median localisation. Sovremennye problemy nauki i obrazovaniya 2014; 2. URL: http://www.science-education. ru/pdf/2014/2/644.pdf.

83. Frolov A.A., Charyshkin A.L. Cholestasiasreasons at patients after hernioplasty with big and huge postoperative ventralnymi hernias. Fundamentalnie issledovania 2013; 9(part 6): 1156-1158. URL: http://www.rae.ru/fs/ ?section=content\&op=show_article\&article_id=10002184.

84. Abbaszade T.N., Anisimov A.Yu. Diagnosis and prevention of early postoperative wound complications in patients with large ventral hernias. Meditsinskiy vestnik Bashkortostana 2013; 3: 21-25.

85. Tuktamyshev V.S., Kuchumov A.G., Nyashin Yu.I., Samartsev V.A., Kasatova E.Yu. Human intraabdominal pressure. Rossiyskiy zhurnal biomekhaniki 2013; 1(59): 22-31.

86. Provotorov V.M., Lyubykh E.N., Ovsyannikov E.S., Malysh E.Yu. Study of functional parameters of cardiovascular and respiratory systems in patients with operated vental hernias. Vestnik eksperimental'noy $i$ klinicheskoy khirurgii 2011; 2: 352-353.

87. Ovsyannikov E.S., Stasyuk O.N. Cardiological aspect of preoperational examination of patients with chronic obstructive respiratory diseases and ventral hernias. Byulleten' meditsinskikh internet-konferentsiy 2013; 3: 495-496.

88. Christoffersen M.W., Helgstrand F., Rosenberg J., Kehler H., Strandfelt P., Bisgaard T. Mesh repair improves long term outcome in patients with a small umbilical or epigastral hernia. Hernia 2014; 18(Suppl 2): S50.

89. Gaydukov K.M., Raybuzhis E.N., Khusceyn A., Teterin A.Yu., Kirov M.Yu. The role of intra-abdominal pressure in impaired pulmonary gas exchange in patients after ventral hernia repair. Vestnik anesteziologii i reanimatologii 2012; 3: 8-12.

90. Losev R.Z., Kozlov V.V., Khmara M.B., Gnilosyr P.A., Gorokhov S.V., Myasoutov R.E. The peculiarities of hernioplasty in patients with consideration for tissue tension ratio. Byulleten' meditsinskikh internet-konferentsiy 2014; 5: 833.

91. Zharkikh V.A., Lavreshin P.M., Gobedzhishvili V.K. Treatment optimization of patients with incisional ventral hernias. Meditsinskiy vestnik Severnogo Kavkaza 2010; 2: 7-9.

92. Pavelets K.V., Vavilova O.G., Lobanov M.Yu., Khairov A.M. The peculiarities of preoperative preparation in patients with extensive and giant incisional ventral hernias. Vestnik Sankt-Peterburgskoy meditsinskoy akademii poslediplomnogo obrazovaniya 2011; 2: 32-36.

93. Aydemirov A.N., Vafin A.Z., Chemyanov G.S., Mnatsakanyan E.G., Laypanov R.M., Chumakov P.I. New technologies in diagnosis and treatment of large and giant ventral hernias. Meditsinskiy vestnik Severnogo Kavkaza 2012; 1: 38-42.

94. Egiev V.N., Shurygin S.N., Chizhov D.V. The comparison of abdominal wal plasty with "heavy" and "light" polypropylene endoprostheses in the treatment of incisional ventral hernias. Moskovskiy khirurgicheskiy zhurnal 2012; 2: 20-23.

95. Zhul'ev A.L., Isaychev B.A., Demin D.B. Intraabdominal hypertension syndrome after large and giant incisional ventral hernia excision. Byulleten' Vostochno-Sibirskogo nauchnogo tsentra SO RAMN 2012; 4(part 2): 56-59.

96. Toktogulov O.Zh. Prevention of complications after surgeries for incisional ventral hernias. Vestnik KGMA im. I.K. Akhunbaeva 2013; 2: 88-90.

97. Samsonov A.A. Atenzionnaya alloplastika $v$ khirurgicheskom lechenii ushchemlennykh gryzh peredney bryushnoy stenki. Avtoref. dis. ... kand. med. nauk [Tensionfree alloplasty in surgical treatment of anterior abdominal wall strangulated hernias. Abstract for the Dissertation of Candidate of Medical Sciences]. Nizhny Novgorod; 2009.

98. Kuznetsov A.V., Kuznetsov Yu.V. Selection of alloplasty in large hernial defects. Vestnik Novosibirskogo gosudarstvennogo universiteta. Seriya: Biologiya, klinicheskaya meditsina 2011; 2: 186-191.

99. Tsverov I.A., Bazaev A.V. The correction of blood coagulation defects for the purpose of complications prevention in surgical treatment of postoperative ventral hernias. Sovremennye tehnologii v medicine 2011; 2: 155-158.

100. Zuvela M., Galun D., Palibrk I., Velikovic J., Nenadic B., Milenkovic M., Djukanovic M., Basaric D., Bogdanovic A., Bidzic N., Miljkovic B., Janjic N., Sumrak S., Milicevic M. How to prevent intraabdominal hypertension and postoperative compartment syndrome following incisional or ventral eventration repair and acute wound bursting — various techniques of component separation with mesh augmentation. Hernia 2014; 18(Suppl 2): S105.

101. Charyshkin A.L., Frolov A.A. Comparative results of hernioplasty in patients with large incisional ventral hernias. Ul'yanovskiy mediko-biologicheskiy zhurnal 2014; 1: 55-63.

102. Gorpinich A.B., Sviridov K.N., Khoroshilova I.I., Semin A.S. Treatment results of patients with incisional ventral hernia. Elektronnyy nauchno-obrazovatel'nyy vestnik "Zdorov'e i obrazovanie v XXI veke" 2012; 14: 81-82.

103. Oommen B., Kim M., Walters A.L., Dacey K.T., Heniford B.T., Augenstein V.A. Predicting perioperative risk for venous thromboembolism after ventral hernia repair. Hernia 2014; 18(Suppl 2): S110.

104. Belokonev V.I., Supilnikov A.A., Pushkin S.Y., Terehin A.A. The new combined sublay-onlay method for incisional hernia repair. Hernia 2014; 18(Suppl 2): S104.

105. Ramirez O.M., Ruas E., Dellon A.L. "Components separation" method for closure of abdominal-wall defects: an anatomic and clinical study. Plast Reconstr Surg 1990; 86(3): 519-526, http://dx.doi.org/10.1097/00006534199009000-00023.

106. de Vries Reilingh T.S., van Goor H., Charbon J.A., Rosman C., Hesselink E.J., van der Wilt G.J., Bleichrodt R.P. Repair of giant midline abdominal wall hernias: "components separation technique" versus prosthetic repair. World J Surg 2007; 31(4): 756-63, http://dx.doi.org/10.1007/s00268-0060502-х.

107. Bleichrodt R.P., de Vries Reilingh T.S., Malyar A., van Goor H., Hansson B., van der Kolk B. Component separation technique to repair large midline hernias. Operative Techniques in General Surgery 2004; 3(6): 179-188, http:// dx.doi.org/10.1053/j.optechgensurg.2004.07.001.

108. Vinnik Yu.S., Nazar'yants Yu.A., Petrushko S.I., Gorbunov N.S., Miller S.V. Sposob kombinirovannoy plastiki gigantskikh posleoperatsionnykh gryzh zhivota [A combined repair technique of giant incisional abdominal hernias]. Patent RF 2405494. 2010.

109. lagudin M.K. Role of staged reconstruction of anterior abdominal wall in large and gigantic postoperative hernias. Khirurgiia. Zhurnal im. N.I. Pirogova 2005; 9: 69-72.

110. Bröker M., Verdaasdonk E., Karsten T. Components separation technique combined with a double-mesh repair for large midline incisional hernia repair. World J Surg 2011; 35(11): 2399-402, http://dx.doi.org/10.1007/s00268-011-1249-6. 
111. Clarke J.M. Incisional hernia repair by fascial component separation: results in 128 cases and evolution of technique. Am Surg 2010; 200(1): 2-8, http://dx.doi. org/10.1016/j.amjsurg.2009.07.029.

112. Bittner R., Bingener-Casey J., Dietz U., Fabian M., Ferzl i G., Fortelny R., et al. Guidelines for laparoscopic treatment of ventral and incisional abdominal wall hernias (International Endohernia Society [IEHS]) - part III. Surg Endosc 2014; 28(2): 380-404, http://dx.doi.org/10.1007/ s00464-013-3172-4.

113. Fedorovtsev V.A., Sidorov M.A., Desyatnikova I.B., Fedaev A.A., Berezova L. The results of laparoscopic plastic surgery of ventral hernias with the use of polypropylene endoproteses. Meditsinskiy al'manakh 2011; 6: 262-264.

114. Nekrasov A.Yu., Kasum'yan S.A., Vorontsov A.K., Sergeev A.V., Bezaltynnykh A.A., Akilov F.A. Laparoscopic hernioplasty of incisional ventral hernias. Kubanskiy nauchnyy meditsinskiy vestnik 2011; 3: 125-128.

115. Bessa S.S., Abdel-Razek A.H. Results of prosthetic mesh repair in the emergency management of the acutely incarcerated and/or strangulated ventral hernias: a seven years study. Hernia 2013; 17(1): 59-65, http://dx.doi.org/10.1007/ s10029-012-0938-x.

116. Zakhidova S.Kh. Tension-free hernioplasty in strangulated ventral hernias. Akademicheskiy zhurnal Zapadnoy Sibiri 2013; 3(46): 36-37. 